\title{
HUBUNGAN SIKLUS MENSTRUASI DENGAN TINGKAT PMS (PREMENSTRUAL SYNDROME) PADA REMAJA PUTRI DI KELURAHAN KECANDRAN KOTA SALATIGA
}

\author{
Nurul Khotimah ${ }^{1}$, Umi Aniroh ${ }^{2}$, Suwanti $^{3}$ \\ Program Studi S1 Keperawatan Universitas Ngudi Waluyo, Ungaran \\ Email : nurulkhotimah@gmail.com
}

\begin{abstract}
ABSTRAK
PMS (Premenstrual Syndrome) merupakan kumpulan gejala fisik, psikologis, dan emosi yang muncul secara siklik dalam rentang waktu 7-10 hari dan menghilang setelah darah haid keluar akibat perubahan hormonal yang berhubungan dengan siklus menstruasi. Penelitian ini dilakukan karena PMS menjadi salah satu masalah besar bagi wanita di Indonesia. Mengetahui hubungan siklus menstruasi dengan tingkat PMS (Premenstrual Syndrome) pada remaja putri di Kelurahan Kecandran Kota Salatiga. Metode Penelitian: Penelitian ini deskriptif korelasi dengan pendekatan cross sectional. Pengambilan sampel dengan proportional random sampling. Besarnya populasi adalah 405 remaja dan besarnya sampel adalah 89 remaja putri. Instrumen penelitiannya berupa kuesioner. Analisis data menggunakan uji statistik Chi Square. Hasil penelitian didapatkan sebagian besar siklus menstruasi normal sebanyak 52 responden (58,4\%), dan tingkat PMS tidak ada gejala hingga ringan sebanyak 68 responden $(76,4 \%)$. Uji statistik Chi Square didapatkan nilai $p$ value $0,613>\alpha=0,05$ yang artinya tidak ada hubungan siklus menstruasi dengan tingkat PMS pada remaja putri di Kelurahan Kecandran Kota Salatiga. Diharapkan bagi remaja putri di Kelurahan Kecandran Kota Salatiga untuk lebih meningkatkan aktivitas olahraga idealnya 3-4 kali per minggu untuk menurunkan resiko PMS.
\end{abstract}

Kata kunci : :Siklus menstruasi, tingkat PMS

\begin{abstract}
The Relationship of The Menstrual Cycle With The Level Of PMS (Premenstrual Syndrome) In Adolescent Adolescents In Kelurahan Kecandran Kota Salatiga.

Premenstrual Syndrome (PMS) refers to a set of physical, psychological and emosional sympstoms which appear cyclic within 7-10 days and disappear after menstrual due to hormonal changes associated with the menstrual cycle. This research was conducted because PMS is one of the serious problems for women in Indonesia. To know the correlation menstrual cycle and levelsof PMS on adolescents at Kecandran Village of Salatiga. The research was descriptive correlation research with cross sectional approach. Sampling used proportional random sampling. The populations were 405 adolescents and the samples were 89 adolescents. The research instrument used a questionaire. Data analysis used statistical test of Chi Square. The results show that menstrual cycle is mostly normal as many 52 respondents (58,4\%), and levels of PMS is mostly without symptoms up to light symptoms as many 68 respondents $(76,4 \%)$. Statistical test of Chi Square get pvalue $0,613>\alpha=0,05$ which means there is no correlation between menstrual cycle and levels of PMS on adolescents at Kecandran Village of Salatiga. It is expected adolescents
\end{abstract}


at Kecandran Village of Salatiga improve their sports activities ideally 3-4 times/week to reduse the risk of PMS.

\section{Keywords $\quad$ :Menstrual cycle, levels of PMS}

\section{PENDAHULUAN}

Menstruasi atau haid adalah proses keluarnya cairan bercampur darah dari vagina perempuan. Cairan ini berasal dari dinding rahim (endometrium) perempuan yang luruh setiap bulan selama masa suburnya kecuali apabila terjadi kehamilan (Winknjosastro, 2009).Panjang siklus haid yang biasa pada manusia ialah 21-35 hari, dan kirakira $97 \%$ wanita yang berovulasi siklus haidnya berkisar antara 18-42 hari. Lama haid biasanya antara 2-8 hari, ada yang 12 hari diikuti darah sedikit-sedikit kemudian, dan ada yang sampai 7-8 hari. Darah yang keluar umumnya sebanyak 10 hingga $80 \mathrm{~mL}$ per hari (Nurnajmi, 2011). Menurut Manuaba (2009), gangguan siklus menstruasi dipengaruhi oleh beberapa faktor diantaranya yaitu perubahan berat badan, olahraga yang berlebihan, stres dan keluhan menstruasi.

\section{Premenstrual Syndrome (PMS)} atau Sindroma Pra Menstruasi adalah sekumpulan gejala fisik maupun psikologis yang muncul sekitar 7-10 hari sebelum menstruasi. Gejala-gejala sebelum menstruasi ini biasanya berkurang atau bahkan menghilang saat fase menstruasi dimulai. Namun, ada juga yang tetap berlanjut hingga hari-hari pertama menstruasi (Kathleen et al, 2010).Beberapa hari sebelum menstruasi, sering kali perasaan perempuan mudah sekali tersinggung, dan mudah marah. Ada yang sampai marah-marah diluar kebiasaannya, dan ada pula yang menjadi cengeng.Ada pula yang mengidamidamkan suatu makanan tertentu. Perubahan emosi seperti ini biasa disebut Premenstrual Syndrome(Sylvia, 2010).Sindrom ini merupakan salah satu masalah yang sangat umum terjadi pada wanita, sehingga PMS merupakan masalah kesehatan masyarakat (Balaha dkk., 2010).

Gangguan menstruasi menjadi permasalahan utama pada wanita di Indonesia. Prevalensi PMS (Premenstrual Syndrome) dibeberapa daerah di Indonesia menunjukkan hasil yang berbeda. Berdasarkan laporan WHO (World Health Organization), PMS memiliki prevalensi lebih tinggi di negara-negara Asia. Berdasarkan laporan yang dilakukan oleh Pelayanan Kesehatan Ramah Remaja (PKRR) dibawah naungan WHO tahun 2005 menyebutkan bahwa gangguan menstruasi menjadi permasalahan utama pada wanita di Indonesia (Lestari, 2013).

Menurut data dari Riset Kesehatan Dasar (Rikesdas, 2010), sebagian besar (68\%) perempuan di Indonesia berusia 10-59 tahun melaporkan haid teratur dan $13,7 \%$ mengalami masalah siklus haid yang tidak teratur dalam 1 tahun terakhir. Masalah haid tidak teratur pada usia 1729 tahun serta 30-34 tahun cukup banyak yaitu sebesar $16,4 \%$.

Pada penelitian yang disponsori oleh World Health Organization (WHO) menunjukkan bahwa $23 \%$ wanita Indonesia mengalami gejala PMS. Berdasarkan studi Premenstrual Syndrome yang ditemukan di 10 negara prevalensinya tertinggi di negara barat sekitar $71-73 \%$, sedangkan di Indonesia angka prevalensi ini mencapai $85 \%$, dari seluruh remaja yang mengalami Premenstrual Syndrome sekitar 60-70\%. Prevalensi Prementrual Syndrome di Indonesia dari 60-75\% mengalami PMS sedang dan berat (Puspitasari, 2014). Angka ini menunjukkan bahwa penderita PMS di Indonesia cukup banyak sehingga perlu dilakukan upaya penanggulangan 
untuk mencegah dan mengatasinya (Pujihastutik, 2012).

Faktor-faktor yang dapat meningkatkan terjadinya PMS di antaranya adalah faktor usia, wanita yang pernah melahirkan, status perkawinan, siklus menstruasi, aktivitas fisik, faktor stres, diet, status gizi, merokok dan minuman beralkohol (Saryono, 2009). Menurut teori

El

Manan(2013)Premenstrual

Syndromemerupakan suatu keadaan yang menerangkan bahwa sejumlah gejala terjadi secara rutin dan berhubungan dengan siklus menstruasi. Dikatakan bahwa seorang wanita yang mempunyai siklus menstruasi teratur akan memiliki tingkat PMS lebih ringan dibandingkan dengan wanita yang memiliki siklus menstruasi tidak teratur. Itu artinya wanita di Indonesia yang mempunyai siklus menstruasi tidak teratur beresiko terjadinya PMS.

Berdasarkan hasil studi pendahuluan yang dilakukan pada tanggal 12 Oktober 2018 di Kelurahan Kecandran Kota Salatiga, peneliti membagikan kuesioner berupa Shortened Premenstrual Assesment Form (SPAF) untuk mengukur tingkat PMS terhadap 15 remaja putri, didapatkan hasil 11 responden yang memiliki siklus menstruasi normal, 9 responden mengalami PMS tingkat tidak ada gejala hingga ringan, dan 2 responden mengalami PMS tingkat gejala sedang hingga berat. Kemudian untuk 1 responden yang mempunyai siklus menstruasi panjang mengalami PMS pada tingkat tidak ada gejala hingga ringan. Dan untuk 3 responden yang mempunyai siklus menstruasi pendek, 2 responden mengalami tingkat PMS tidak ada gejala hingga ringan, dan 1 responden mengalami tingkat PMS gejala sedang hingga berat.

Berdasarkan dari uraian di atas maka peneliti tertarik untuk meneliti tentang "Hubungan Siklus Menstruasi Dengan
Tingkat PMS Pada Remaja Putri Di Kelurahan Kecandran Kota Salatiga”.

\section{METODE PENELITIAN}

Penelitian ini adalah deskriptif korelatif dengan menggunakan cross sectional. Variabel independent dalam penelitian ini adalah siklus menstruasi. Variabel dependent dalam penelitian ini adalah tingkat PMS. Populasi dalam penelitian ini adalah semua remaja putri. Sampel yang diperlukan dalam penelitian ini sebanyak 89 responden. Teknik pengambilan sampel pada penelitian ini dilakukan dengan metode proportionate random sampling. Instrumen dalam penelitian ini menggunakan kuesioner dan data primer yaitu kuesioner tingkat PMS menggunakan SPAF. Analisis data menggunakan Chi Square statistik ChiSquare.

\section{HASIL DAN PEMBAHASAN}

\section{A. Analisis Univariat}

1. Siklus menstruasi pada remaja putri di Kelurahan Kecandran Kota Salatiga

Tabel 1. Distribusi frekuensi siklus menstruasi pada remaja putri di Kelurahan Kecandran Kota Salatiga

\begin{tabular}{ccc}
\hline $\begin{array}{c}\text { Siklus } \\
\text { Menstruasi }\end{array}$ & Frekuensi & $\begin{array}{c}\text { Persentase } \\
(\boldsymbol{\%})\end{array}$ \\
\hline Panjang & 8 & 9 \\
Normal & 52 & 58,4 \\
Pendek & 29 & 32,6 \\
\hline Total & 89 & 100 \\
\hline
\end{tabular}

Berdasarkan tabel diatas dapat dilihat bahwa siklus menstruasi remaja putri mayoritas siklus menstruasi normal yaitu sebanyak 52 responden $(58,4 \%)$.

2. Tingkat PMS pada remaja putri di Kelurahan Kecandran Kota Salatiga 
Tabel 2 Distribusi frekuensi tingkat PMS pada remaja putri di Kelurahan Kecandran Kota Salatiga

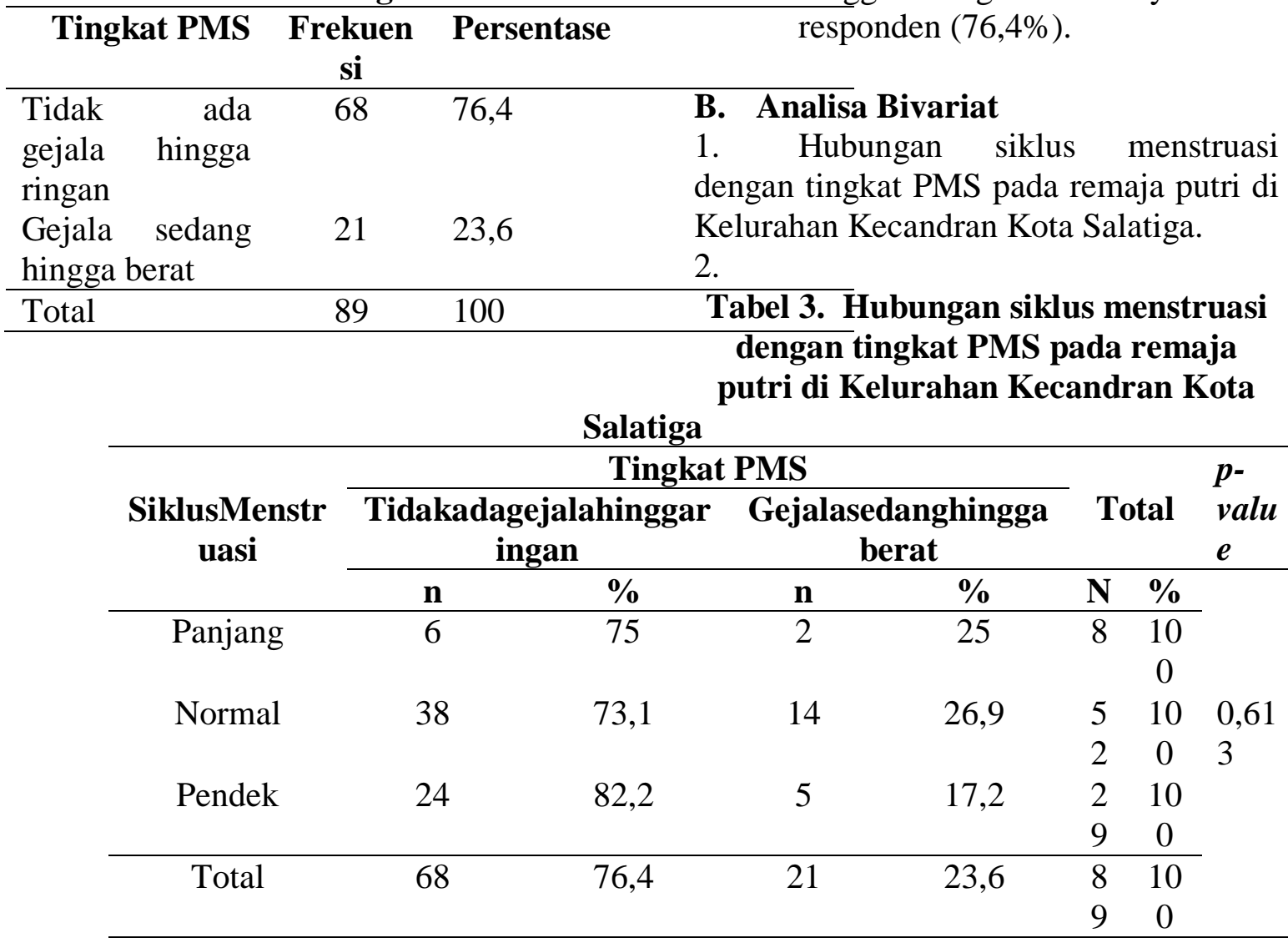

Berdasarkan tabel diatas dapat dilihat bahwa remaja putri yang mengalami tingkat PMS tidak ada gejala hingga ringan sebanyak 38 responden $(73,1 \%)$ dengan siklus menstruasi normal. Hasil uji statistik menggunakan uji chi square didapatkan nilai $\mathrm{p}$ value sebesar 0,613 $(>0,05)$ yang berarti tidak ada hubungan siklus menstruasi dengan tingkat PMS pada remaja putri di Kelurahan Kecandran Kota Salatiga.

\section{PEMBAHASAN}

\section{A. Univariat}

1. Gambaran Siklus Menstruasi Pada Remaja Putri Di Kelurahan Kecandran Kota Salatiga

Berdasarkan hasil penelitian dapat

dilihat bahwa mayoritas responden memiliki siklus menstruasi normal yaitu sebanyak 52 responden $(58,4 \%)$. Remaja putri di Kelurahan Kecandran Kota
Berdasarkan tabel diatas dapat dilihat tingkat PMS mayoritas adalah tidak ada gejala hingga ringan sebanyak 68 responden $(76,4 \%)$ 
konsumsi alkohol, status gizi kurang atau lebih, asupan zat gizi, dan aktivitas fisik.

\section{Gambaran Tingkat PMS Pada Remaja Putri Di Kelurahan Kecandran Kota Salatiga}

Berdasarkan hasil penelitian dapat dilihat bahwa mayoritas responden memiliki tingkat PMS tidak ada gejala hingan yaitu sebanyak 68 responden $(76,4 \%)$. Hal ini sejalan dengan laporan angka prevalensi PMS di Indonesia yang mencapai $85 \%$ dari seluruh populasi wanita usia reproduksi (Suparman, 2011).

Sindrom premenstruasi merupakan gejala-gejala yang terkait dengan siklus menstruasi yang terjadi lima sampai dengan sebelas hari sebelum menstruasi dan hilang setelahnya (Khamzah, 2015). Gejala sindroma premenstruasi meliputi dari gejala fisik, emosi dan perilaku (Rahmadani, 2013).

Responden dengan tingkat PMS tidak ada gejala hingga ringan 33\% responden memiliki siklus menstruasi normal, $3 \%$ responden mengalami menarche yang terlalu dini, $1 \%$ responden memiliki riwayat amenore, $25 \%$ responden sedang mengalami stres, $34 \%$ responden tidak pernah melakukan olahraga, $21 \%$ responden sedang menjalani diet dan 3\% responden merokok. Dapat disimpulkan responden dengan tingkat PMS tidak ada gejala hingga ringan faktor risiko berupa aktivitas fisik, koping stres, kecukupan gizi, dan gaya hidupnya lebih baik dibandingkan dengan responden yang memiliki tingkat PMS gejala sedang hingga berat.

Hal ini didukung dengan teori Michel dan Bonnet (2014), seperti halnya faktor aktivitas fisik (olahraga), faktor psikologis, faktor gaya hidup dan juga faktor tercukupinya gizi dalam tubuh. Sehingga apabila faktor yang lain terpenuhi, risiko PMS tetap dapat diturunkan.

\section{B. Analisa Bivariat \\ 1. Hubungan Siklus Menstruasi Dengan Tingkat PMS Pada Remaja}

\section{Putri Di Kelurahan Kecandran Kota Salatiga}

Hasil uji statistik menggunakan uji chi square didapatkan nilai $\mathrm{p}$ value sebesar 0,613 $(>0,05)$ yang berarti tidak ada hubungan antara siklus menstruasi dengan tingkat PMS pada remaja putri. Hasil penelitian ini tidak sesuai dengan teori El Manan (2013) yang mengatakan Premenstrual Syndromemerupakan suatu keadaan yang menerangkan bahwa sejumlah gejala terjadi secara rutin dan berhubungan dengan siklus menstruasi. Di katakan bahwa wanita yang memiliki siklus menstruasi tidak normal (siklus menstruasi panjang dan pendek) akan cenderung beresiko mengalami tingkat PMS yang lebih berat.

Penyebab tidak berhubungannya variabel ini mungkin disebabkan adanya faktor hormonal yang lebih dominan, yaitu keseimbangan antara hormon estrogen dan progesteron. Hal ini dikarenakan hormon adalah faktor utama penyebab dari PMS, yaitu adanya ketidakseimbangan kerja dari hormon estrogen dan progesteron (Andrews, 2011, Dickerson dkk., 2013). Teori lain menunjukkan bahwa ternyata, adanya kelebihan estrogen atau defisit progesteron dalam fase luteal (pasca ovulasi) dari siklus menstruasi akan menyebabkan PMS (Saryono dan Sejati, 2009).

Hal ini didukung oleh teori Dieny (2014), bahwa terdapat beberapa faktor yang mempengaruhi siklus menstruasi diantaranya genetik, ras, usia, penyakit, pertumbuhan alat reproduksi, hormon, obat-obatan kontrasepsi, stress, merokok, konsumsi alkohol, status gizi kurang atau lebih, asupan zat gizi, dan aktivitas fisik.

\section{KESIMPULAN DAN SARAN Simpulan}

1. Mayoritas siklus menstruasi yang dialami remaja putri di Kelurahan Kecandran Kota Salatiga adalah siklus normal (21-35 hari) sebanyak 52 responden $(58,4 \%)$.Dan sebagian 
besar tingkat PMS yang dialami remaja putri di Kelurahan Kecandran Kota Salatiga adalah tingkat PMS dalam kategori tidak ada gejala hingga ringan yaitu sebanyak 68 responden $(76,4 \%)$.

2. Tidak ada hubungan antara siklus menstruasi dengan tingkat PMS pada remaja putri di Kelurahan Kecandran Kota Salatiga, karena nilai $p$-value sebesar $0,613>\alpha(0,05)$.

\section{Saran}

1. Remaja putri di Kelurahan Kecandran Kota Salatiga

Diharapkan untuk meningkatkan aktivitas fisik dengan melakukan olahraga idealnya 3-4 kali per minggu. Serta diharapkan untuk menjaga koping stres dengan baik mungkin dengan cara meluangkan sedikit waktu untuk refresing sehingga tidak terlalu terbebani dengan tugas sekolah yang menumpuk.Karena dengan melakukan aktivitas fisik yang cukup dan koping stres yang baik dapat mengurangi resiko terjadinya PMS.

2. Bagi institusi kesehatan

Institusi kesehatan disini yaitu dari pihak Puskesmas yang banyak dan sering berhubungan langsung dengan masyarakat. Yaitu diharapkan dapat memberikan penyuluhan ke masyarakat dengan melakukan promosi kesehatan berupa pembuatan pedoman atau media kesehatan yang mudah dipahami dan menarik yang berkaitan dengan PMS.

3. Tenaga kesehatan

Memberikan penyuluhan kepada wanita usia subur (usia reproduksi) mengenai Premenstrual Syndrome (PMS), serta upaya untuk mengurangi gejalanya sehingga PMS tidak lagi menjadi masalah kesehatan umum yang paling banyak dilaporkan oleh wanita usia reproduksi dan tidak menjadi gangguan PMS yang lebih berat yang dapat menganggu aktivitas sehari-hari.

\section{DAFTAR PUSTAKA}

Allen, S. (1991). The Shortened Premenstrual Assssment Form. J Reprod Med. Vol 36 (11): 769-72.

Andrews dan Gilly. (2009). Buku Ajar Kesehatan Reproduksi Wanita. Vol 2. Jakarta: EGC.

Devi Mazarina, (2013). Hubungan Kebiasaan Makan dengan Kejadian Sindrom Pramenstruasi pada Remaja Putri. Teknologi dan Kejuruan. Vol. 32, No. 2, September 2013: 197-208.

El Manan. (2013). Kamus Cerdik Kesehatan Wanita. Yogyakarta: Flash Book.

Elvira dan Sylvia. (2010). Sindrom PraMenstruasi Normalkah?. Jakarta: FKUI.

Ilmi, A. F., \& Utari, D. M. (2018). Faktor Dominan Premenstrual Syndrome Pada Mahasiswi ( Studi Pada Mahasiswi Fakultas Kesehatan Masyarakat Dan Departemen Arsitektur Fakultas Teknik, Universitas Indonesia ) The Dominant Factors Of Premenstrual Syndrome In University Student ( Study At Female Students Of Public Health And The Department of Architecture , Faculty of Engineering, University of Indonesia ), 39-50.

Kathleen, M., Lustyk, B., dan Gerrish, W.G. (2010). Premenstrual Syndrome Dysphoric Disorder: Issues of Quality of Life, Stres and Exercise. Springer Science + Bussiness Media LCC, USA. 
Lestari, T. (2013). Hubungan Aktivitas Olahraga Remaja dengan Kejadian Premenstrual Syndrome pada Siswi MAN 1 Bukit Tinggi. Prima Nusantara Journal.

NIH. (2014). Premenstrual Syndrome [Online] United States: National Institute of Health.

Notoatmodjo, S., (2010). Pendidikan dan Perilaku Kesehatan. Rineka Cipta. Jakarta.

Nur Najmi. (2011). Buku Pinter Menstruasi. Yogyakarta : Buku Biru.

Pujihastutik EK. (2012). Hubungan Antara Rasio Lingkar Pinggang Panggul, Asupan Zat Gizi dan Aktivitas Fisik dengan Kejadian Syndrome Premenstruasi pada Siswi MTs N Mlinjon Filial Truck Klaten tahun 2012. Jurnal Kesehatan Masyarakat 2012; 1 (2): 572-7.

Puspitasari. R., dkk. (2014). Pengetahuan Mahasiswi Universitas Al Azhar Indonesia Terhadap Premenstrual Syndrome. Jurnal AL-AZHAR INDONESIA SERI SAINS DAN TEKNO,. Vol. 2, No. 3.

Winkjosastro. 2009. Ilmu Kebidanan. Jakarta : Yayasan Bina Pustaka. 